\title{
MERIT IS NOT FOR EVERYONE: THE PERCEPTION OF BLACK MANAGERS ABOUT THEIR PROCESS OF CAREER MOBILITY
}

\author{
Mérito não é para qualquer um: a percepção de gerentes negros sobre \\ 0 seu processo de ascensão profissional
}

\author{
Andréa Alcione de Souza* \\ Rafaela Cyrino Peralva Dias**
}

\begin{abstract}
Based on research conducted in Belo Horizonte, with 25 black managers, this article analyzes how the career mobility discourse is based on the idea of personal merit. Considering this central problem and authors such as Pierre Bourdieu, Jessé Souza and Carlos Hasenbalg, the research analyzed the assumptions, functionalities and productive character that the idea of personal merit assumes in the interviewees' discourse. The results obtained point to a perception of the process of moving up in the organization career path that has strong meritocratic components; a perception that ignores or minimizes the social, emotional, moral and economic preconditions that interfere in the differential performance obtained by individuals. Moreover, this perception implies a disqualification of any argument that reinforces the racial barriers in their upward career mobility processes, which contributes to conceal the political, economic and social dimension of racism in the country.
\end{abstract}

Keywords: Merit. Race. Career mobility.

\begin{abstract}
RESUMO
0 artigo analisa, a partir de uma pesquisa realizada em Belo Horizonte com 25 gerentes negros, como o discurso de ascensão profissional é fundado na ideia de um mérito pessoal. Através de autores como Pierre Bourdieu, Jessé Souza e Carlos Hasenbalg, a investigação analisou, a partir desta problemática central, os pressupostos, as funcionalidades e o caráter produtivo que a ideia de mérito pessoal assume no discurso dos entrevistados. Os resultados obtidos apontam, no discurso dos gestores, para uma percepção acerca do processo de ascensão profissional com fortes componentes meritocráticos, percepção esta que ignora ou minimiza as pré-condições sociais, emocionais, morais e econômicas que interferem no desempenho diferencial obtido pelos indivíduos. Acrescenta-se, ainda, que esta percepção implica em uma desqualificação de qualquer argumentação que reforce as barreiras raciais em seus processos de ascensão profissional, o que contribui para ocultar a dimensão política, econômica e social do racismo no país.
\end{abstract}

Palavras-chave: Mérito. Raça. Ascensão profissional.

\footnotetext{
* Professora do Departamento de Administração da Pontifícia Universidade Católica de Minas Gerais (PUC- Minas). Doutora em Ciências Sociais pela Pontifícia Universidade Católica de Minas Gerais (PUC-Minas). E-mail: andrea.asouza@uol.com.br. ORCID: 0000-0002-6009-2221

** Professora Adjunta do Programa de Pós-graduação em Ciências Sociais da Universidade Federal de Uberlândia (UFU). Doutora em Sociologia pela Universidade Federal de Minas Gerais (UFMG). E-mail: rafaelacyrino@ hotmail.com. ORCID: 0000-0003-1575-1483
} 


\section{INTRODUCTION}

T

he level of a population's social mobility is an important dimension in understanding how the country's economic development contributes to the reduction of social inequalities. The results of economic development in Brazil are distributed unequally, privileging some individuals over others and reinforcing the idea of the existence of social barriers that compromise equal access of certain groups to opportunities for upward mobility. In this process, when an individual reaches higher positions in the social or occupational structure, there is the possibility of new economic, cultural, symbolic and educational gains, as well as changes in values and attitudes.

After analyzing the racial inequalities in the Brazilian labor market, we find explicit evidence of the differentiated situations and conditions of blacks and whites, whether at the moment of insertion, construction of the occupational trajectory, or in relation to the possibility of career mobility (HASENBALG, 2005).

Marked by complexity in terms of identification and understanding, racial discrimination in Brazil, as an important dimension in our set of social inequalities, has its own characteristics that limit its recognition. However, its systematic manifestation, whether it is evident or diffuse, keeps imposing barriers that negatively influence the life cycle of half of the Brazilian population. Due to the fact that racial barriers in Brazil are not always easy to identify, it is important to develop studies that seek to understand whether the black population who ascended to higher-status occupations conceives and explains their upward mobility process only from the individual point of view and, consequently, whether there is the possibility for critical perception of the social constraints that impact the upward mobility processes of the black population.

Therefore, based on research carried out in the city of Belo Horizonte (in the state of Minas Gerais) in 2012, this paper seeks to analyze the perception of black managers in relation to their career mobility process, aiming to identify and evaluate, among the interviewees, the recurrence of a discourse centered on personal merit. From this perspective, we can ask ourselves: in order to be recognized as members of a higher social class in a stratified society, would black managers have to assume and naturalize the meritocratic discourse and deny race-based affirmative actions? In general terms, this analysis sought to understand how the career mobility discourse manifested by black managers is based on the idea of personal merit, ignoring or minimizing the social, emotional, moral and economic preconditions that interfere in the different performances of individuals.

Our methodology focused on content analysis of interviews conducted with 25 managers working in public and private companies, aiming to critically investigate the presence of discourse focused on the idea of personal merit as an explanation for their career advancement. The theoretical basis for the analysis of the recurrence of such discourse and its productive consequences was the characterization of the meritocratic discourse carried out by Jessé Souza (2011), especially concerning the main features elected by the author as structuring such discourse.

In addition to the main objective outlined above, we sought to analyze the assumptions, functionalities and productive character that the idea of personal merit assumes 
in the discourse of the interviewees, using the theoretical contributions of authors such as Pierre Bourdieu (2013), Jessé Souza (2011) and Carlos Hasenbalg (2005). The productive character of the meritocratic discourse indicates that it significantly contributes to generate certain interpretations of the racial discrimination events experienced by the black managers, to justify political positions in relation to the so-called affirmative action policy, to legitimize conceptions of justice that ignore the weight of social and racial inequalities, among others, helping to reinforce a technocratic conception of the world that is not sensitive to the structural problems present in our society.

\section{MERITOCRATIC DISCOURSE AND THE NATURALIZATION OF SOCIAL INEQUALITIES}

An analysis of the historical and functional components that the discourse based on personal merit acquires in the configuration of the so-called modernity becomes important, when considering, as Livia Barbosa (2003) proposes, that meritocratic ideology constitutes one of the main components of social hierarchization of modern societies. In fact, the "project of modernity", by proposing a rupture with the social order instituted by the old regime, also meant a rupture with some values associated with it and also with the structure of domination that socially legitimated it .

Max Weber (2012), the author who provided the theoretical basis for the development of the "sociology of domination", considers that the bureaucratic administration, fully developed in the Modern State, is highly functional for the development process of the large capitalist enterprise. In fact, because it is based on rationality, such bureaucratic domination is an essential factor for the capitalist system, whose development created a historical need for a continuous, rigorous, intense and calculable administration (WEBER, 2012, p. 146).

This bourgeois and capitalist society is founded on the assumption of equality and freedom, and values rationality, individuality, competition and the ethics of performance. What Max Weber (2004) characterized as "the spirit of capitalism" consists precisely in a life course based on economic rationalism and sustained by a strong devotion to work, performance, and economic success. The predominance of this ethics of performance indicates that the positions of individuals in society must be a consequence of their personal merits, and this is the notably ideological component of the meritocratic system which is typical of modern societies (BARBOSA, 2003).

The ideological basis of this system can be found in Max Weber's (2012) description of the ideal type of bureaucratic domination, presented by the author as a typically modern form of administration. In contrast to the traditional domination, which is based on the belief in the sanctity of traditional orders and powers of the lord, the modern society, modeled on bureaucratic administration, inaugurates a type of domination allegedly founded on reason. The rational character of bureaucratic administration conveys the idea that domination is not only rational but fair, since it occurs by virtue of "knowledge" and not due to the moods and arbitrariness of a "lord". It is, therefore, based on this legitimizing rationality that the dominated and the dominant groups are, in a certain way, levelled off; This is observed, for instance, in the institution of a universal recruitment of those who are the most qualified professionally (WEBER, 2012). 
This meritocratic component, which, in modern societies, is associated with an ethics of performance, is informed by the presupposition of equality, which legitimizes social hierarchies by appealing to a criterion of justice that seeks to reward the best, the most talented, the most qualified. However, this supposedly " equality before the law" between individuals and the leveling of the dominated and the dominant group (WEBER, 2012) contributes to conceal the real and concrete reasons for social inequalities (their material basis), riddled with contradictions. It is from this perspective that we approach, in this study, the ideological components of meritocracy, seen as a view that, by naturalizing the social inequalities which are typical of modern societies, contributes to its reproduction, justification and legitimation.

Therefore, recovering the ideological origin of meritocratic thinking in modern societies is important because it allows us to critically analyze this presupposition of equality on the basis of this ideology, since the more unequal the society, the more inadequate it proves to be. In the case of Brazilian society, constituted by expressive inequality, the intransigent defense of personal merit contributes to creating a common sense in which "inequalities" are perceived as "fair" because they are understood as the result of effort and differential performance among individuals.

Souza (2011) observes that the main support for this meritocratic ideology is forgetting the social within the individual, because "any social determination that builds individuals destined to success or failure has to be carefully silenced" (SOUZA, 2011, p. 43), so that, in this way, a conception of success based solely on the abilities, capacities and ingenuity of the individual can prevail. Concealing, therefore, the social determinations that influence the individual performance, one justifies and legitimates all kinds of privilege in the context of modernity.

Associated with this "democratic" assumption, there is economicism, a way of thinking that conceives "society as composed of a set of homo economicus, that is, rational agents that calculate their relative chances in the social struggle for scarce resources with the same dispositions of behavior and the same capacities of discipline, self-control and responsibility" (SOUZA, 2011, p.17). Social or professional mobility would be the result of the articulation between individual attributes such as education, age, qualification and the structural conditions of economic growth.

Jessé de Souza (2011), in A ralé brasileira: quem é e como vive (The Brazilian scum: who they are and how they live), discusses how meritocratic and economic thinking, which is typical of modern societies, contributes to the reproduction and deepening of social inequalities. Souza supports the idea that the legitimization of the modern world as a "just" world is based on meritocracy. In the case of Brazil, the author affirms that the culture of merit is based on the belief that, in contemporary Brazilian society, blood and birth barriers, present in pre-modern societies, are no longer impediments to career mobility, and that today, only the differential performance of individuals is taken into account.

It must also be considered that Brazilian society, as Souza (2011) emphasized, has historically been characterized by an opposition between a social class that has been excluded from all material and symbolic opportunities of social recognition and the other social classes that are, albeit differently, included. In this system of symbolic opposition 
informed by values of superiority and inferiority, the process of social competition means getting as close as possible to the sphere of values socially worthy of merit and recognition.

According to Souza (2011), the ideology of individual merit implies forgetting the "social" sphere and disregarding all the social, emotional, moral and economic preconditions that allow the creation of the productive and competitive individual. Based on this ideology, "failure" is understood from the individual point of view, which tends to reconfigure the very notion of justice, since the more a competitive system is based on meritocracy, the more merit is considered the ideal measure of justice.

The notion of social justice based on individual merit is strongly supported by the project of modernity, and can be observed, in an exemplary manner, in the "Declaration of the Rights of Man and Citizen" of 1789, which states a constitutive principle of most of the so-called "Modern" Constitutions: that all citizens are equal before the law and are equally admissible to all public places and jobs, with no distinction other than their virtues and talents.

Souza (2011) also notes that the definition of a specifically modern social justice means that societies must give each and every person according to their own merit, while maintaining the illusion that social equality is thus preserved. In fact, as noted by Weber (1999), the very structure of domination creates the need to consider the contrast that engenders privilege as being legitimate and the situation of "the other" as being the result of some kind of guilt. It is in this sense that the "legend" of every privileged group is its natural superiority and the consequent assumption that "every individual has the fate he/she deserves" (WEBER, 1999, p. 197).

It is important to stress that Jessé de Souza (2011) analyzes the process of reproduction of social inequalities, in which the market, the State, a "Science" and common sense actively participate, based on certain "current social consensus, we all participate in" (SOUZA, 2011, p. 24). This means considering that the dominant ideology that naturalizes inequality and "accepts to produce 'people' on the one side and 'subpeople' on the other" (SOUZA, 2011, p. 24), even being reproduced by individuals on a daily basis, cannot be analyzed without taking into consideration this process of social production and reproduction informed by the dominant, legitimate and authorized knowledge in a given society. As Bourdieu (2013, p. 438) points out, in this process of social reproduction, "the social order is progressively inscribed in people's minds", making it difficult to perceive the limits and contradictions of the prevailing social mythology.

These social consensuses, mute and silent, can articulate both solidarities and deep prejudices (SOUZA, 2011, p. 409). In addition, it is important to consider that "every process of social domination is based on forms of symbolic violence, that is, on mechanisms that obscure and mitigate real violence and make it acceptable and even desirable for even its greatest victims" (SOUZA, 2011, p. 398). It is in this sense that we must face the challenge of articulating what has been separated: the individual and the social, since it is not enough to recognize the force of the dominant interpretations, it is also necessary to recognize that "there is no unjust social domination without it being legitimized as good and just" (SOUZA, 2011, p. 419). And facing this challenge implies challenging latent social consensuses, which operate in such a way that they conceal or minimize social conditioning that helps explain differences in performance among individuals in a given society. 


\section{THE SYSTEM OF SOCIAL DISTINCTIONS AND THE SOCIAL STRUGGLE FOR SCARCE RESOURCES}

In the analysis of the notably productive character that the meritocratic discourse assumes in the interviewees' speech, it becomes important to revisit the contribution of Pierre Bourdieu (2013), in particular the way the author analyzes the process of reproduction and legitimation of the established social order. Bourdieu, by understanding the social structure as a hierarchical system that establishes relations of power and privilege, is interested in both the material aspects that underlie the process of domination and its symbolic components.

The author analyzes social structure as a field of struggles in which positions and position-taking are defined relationally, based on the dominant classification system that is at the origin of the representations. This dominant classification system refers to the most fundamental opposition of the social order: the opposition between the dominant and the dominated, the basis of the social hierarchy and the system of social distinctions. Thus, in this field of struggles, individuals and groups devise strategies aimed at maintaining or improving their position in the social hierarchy. Therefore, according to this perspective, it is understandable to find individuals or families who seek to approach the habitus of the "elite" of the dominant group, whether consciously or not, in order to preserve or elevate their social position in the structure of class relations, since "the primordial experience of the world is the doxa, adherence to the relations of order that are accepted as evident" (BOURDIEU, 2013, p. 438).

It is interesting to focus a little more on how Bourdieu (2013) describes and explains the workings of classification systems, which are extremely effective, according to the author, for the strengthening of representations which are structured according to the classification. In this process, riddled with antagonisms, the signs of distinction that express class membership play a fundamental role in the reproduction of the system. Such signs of distinction are not restricted to the material domain but imply symbolic aspects, which indicate whether or not the individual is recognized as a member of a given class / class fraction. In emphasizing the transfer of immaterial values in the reproduction of social classes and their privileges, Jessé de Souza (2011) states that the process of social competition does not begin in school, as is generally believed, because the so-called cultural capital is acquired by the individual from an early age, in the process of primary socialization, in which both the habits, attitudes and behavior that are typical of a particular class are learned, and those that are considered the "reference" in terms of "superiority", which make up the socially valued lifestyles.

In the process of producing differentially equipped individuals for social competition, Jessé de Souza (2011) emphasizes two fundamental aspects. One of them is related to the interest families show in fostering the self-confidence of the individual, so that they learn that they are loved unconditionally by their parents. This confers, according to Jesse, to the one who has it, the certainty of their own value. Another fundamental learning for the individual to be better qualified for the process of social competition is related to the disciplinary mechanism, as when one learns to eat at the right times, to do the housework, to clean the room, to know how to behave in social environments, among others. These are 
some learnings that integrate the so-called "cultural capital", which is continually covered up by the mechanisms of social domination, although it helps to explain the differential performance of individuals in a given society. Especially for black professionals, because their color or race can be a defining element of their 'social place.'

\section{SOCIAL MOBILITY AND RACIAL INEQUALITIES IN BRAZILIAN SOCIETY}

Most studies about race relations in Brazil analyze the participation of blacks in Brazilian society at various stages of our development, trying to understand the impact of our historical legacies in contemporary forms of racial discrimination. However, the visibility of racial inequalities imposes the need to broaden the studies that help us understand how and why, even one hundred years after the abolition of slavery, the majority of blacks still integrate the most vulnerable portion of the Brazilian population.

After slavery, race discrimination in Brazil occurred by means of impoverishment and verbal abuse, through the use of the individual's social class and skin color. In this country, there is this general idea that points to the inferiority of African peoples and, consequently, to the low cultural level of their descendants.

According to Guimarães (1999), in Brazil, racism had two distinct phases. At first, racial discrimination was ostensible but informal and influenced by class and gender discrimination. This fact culminated in segregation in public and private spaces: bars, restaurants and churches. Today, racial discrimination follows market mechanisms, isolating individuals rather than groups; or psychological mechanisms of inferiorization of individual characteristics, culminating in self-exclusion. Most Brazilians, while admitting the existence of racism, declare themselves non-racists. Thus, there is a tendency of disguising racism as class discrimination, manifested in social relations. So, in our country, even with most Brazilians denying racism, racial prejudice is manifested/revealed in social practices. (RODRIGUES, 1995).

A central point of this discussion refers to Blacks' career mobility and their under-representation in significant positions in public and private organizations. In fact, the question of Blacks' social mobility has been present in the history of Brazilian society since the colonial period. An important study on the upward mobility of Blacks in Brazilian society was presented by Gilberto Freyre (2006) in his writings. His perception of Brazil as a culturally integrated country, whose main evidence would be miscegenation, resulted in the acknowledgement of the mobility of the bachelor and mulatto. By incorporating physical traits of both whites and blacks, and with the patronage of some benefactor, the mulatto could pursue a career and change their social status.

In another context, Thales de Azevedo analyzed the social upward mobility of Black people in the state of Bahia, considering an industrialized society and the research resulting from the UNESCO project ${ }^{1}$. According to Azevedo (1996), it is only partially true that there is

1. From 1950 to 1953, the United Nations Educational, Scientific and Cultural Organization (Unesco) financed a series of research projects about race relations in Brazil in order to understand and disseminate to other countries the secret of the supposedly 'racial harmony' in Brazilian society. During that period, after World War $\mathrm{II}$, the international context still was of perplexity in relation to the crimes committed due to racial differences. 
no racism in Bahia, considering the large number of black and brown people in the composition of its population. Part of the white population of the state considered black people as inferior both socially and biologically. This group believes that the high number of blacks is responsible for the State's economic backwardness. However, according to Azevedo (1996), this type of discrimination used to be moderate and restricted to certain sectors. Due to their skin color, which reminds us of African slaves, accustomed to manual services and who were members of the poorer strata of society, black people were at a disadvantage. Nonetheless, since Bahia is a multiracial and class society, the upward mobility of blacks would be solely and exclusively conditioned by their individual abilities, and thus, this group would compete on a level playing field with whites. Azevedo (1996) further states that a higher educational level, adherence to the dominant culture (of whites) and protective mechanisms, such as the help of 'godparents' (sponsors), were fundamental for the upward mobility of blacks. Patronage, along those lines, was termed by the author as a 'spiritual kinship.' This question refers to the relations of affection and friendliness between blacks and whites translated, at times, into help and protection, even though they were not related by blood.

The studies under this project by Unesco, that dealt with racial relations in Rio de Janeiro and São Paulo (BASTIDE \& FERNANDES, 1955; COSTA PINTO, 1953) focused on the forms of integration of black people into the class system and on social stratification, besides analyzing the associative life and the nature and function of racial prejudice in that region. The interpretation of Florestan Fernandes (1965), who analyzed the racial issue in São Paulo, was fundamental for later studies on the integration of Blacks into the class structure. According to the author, the exclusion of blacks in the first stage of São Paulo's industrialization process in 1930 was a consequence of a government policy which encouraged immigration.

It is known that immigration had a dual role in the emerging capitalist society in Brazil: to dissociate free labor from slave labor, and to improve the country's ethnic-racial profile. Hasenbalg (1999) adds that this interpretation must consider an important phenomenon that contributed to the late incorporation of blacks into the urban-industrial environment of the time: the majority of blacks was concentrated in economically less dynamic regions, such as the Northern region and the Central-west. Outside the Southeast, whites, blacks and mulattos remained linked to agriculture from 1940 to 1950 . This situation, coupled with inequalities in education and income, strongly influenced the distribution of racial groups in the occupational strata that emerged with industrialization. Moreover, the optimistic argument that the development of a class society in Brazil could favor the social integration of blacks, present in the analysis of Florestan Fernandes, was not fulfilled either. While in a slave society the right of ownership over the slave and the violence of the owner was sufficient to secure domination over blacks; in a class society, on the other hand, where all are equal before the law, "it was necessary to develop social mechanisms that ensured, in the name of natural inequality, the accommodation of blacks to the system of asymmetrical positions and advantages" (HASENBALG, 2005, p. 118).

Assigning negative qualities to blacks, through racism, is understood as a mechanism of domination that primarily aims to maintain the privileges of the white population in the social structure. In addition, it has been fundamental in the labor market to ensure the availability of cheap and abundant labor and to perpetuate a culture that, through discriminatory practices and explicit or symbolic violence, has limited the opportunities of blacks in 
the process of social mobility. "Racism as a mechanism of social selection places non-white Brazilians at a disadvantage in the competitive process of individual upward social mobility and confines them to the bottom of the social hierarchy" (HASENBALG, 1999, p. 41). Racial discrimination has an even worse perverse effect: it makes blacks regulate their aspirations to culturally accepted stereotypes, which define 'the position of whites' and the 'position of blacks' in the social structure. Racism has worked and continues to function as an instrument of disqualification of blacks in the labor market, reserving the most precarious and low-paid jobs for them. This situation persists to this day.

Regarding the insertion in the productive structure, in addition to entering the labor market earlier, blacks also take longer to retire.

Difficulties in the maintenance and reproduction of black families imply the early entry of their members into the labor market, which may result in an obstacle to a full-fledged schooling experience, accumulating damages to the future quality of the workforce. (DIEESE, 2001, p. 132).

The issue presented above brings us back to the veiled forms of racism in Brazilian society, which are subtly manifested, sometimes almost imperceptible. In the Brazilian social imaginary there is a place for blacks and a place for whites and one way of perceiving the distinction of places is to observe the "strangeness" of seeing a black person outside their place. This place, like any other, has coordinates of its location. Santos (1995) selects the phenotype (black), social status (poor), cultural heritage (popular), historical origin (African ancestry) and identity (self-definition and definition by the other) as coordinates to fix (position) blacks in certain spaces. Thus, there is this sensation of strangeness when blacks are seen in command posts, in leadership positions, in high positions in the public sphere, in the legislative branch, and in the judiciary, and so on, because they would be out of "their place": on the basis of the stratified class structure of the Brazilian capitalist model, reproduced in all spheres of social life, including in the labor market. Thus, these location coordinates of blacks in Brazilian society, marked by inequality, end up determining the positions that blacks should primarily occupy, namely the positions destined to reproducing cheap labor, both in training and in the remuneration of the workforce.

According to Hasenbalg (2005), in Brazil, the black population in the labor market is also subject to the mechanisms of class domination that affect other groups. Nevertheless, blacks still suffer a peculiar discrimination as a result of their racial condition. The accumulation of disadvantages caused by being black in Brazil, says Osório (2004), proves the existence of racial barriers in the process of career mobility. The over-representation of blacks in the lowest strata of the labor market implies a disadvantage, from the outset, for the new generations. In addition, the origin of poverty, the occupation of parents and the difficulty of access to education and qualification limit the career mobility of this social group.

Carlos Hasenbalg (1999) analyzed the social mobility of whites and blacks, unfolding his study in three stages: intergenerational mobility; the influence of the parents' social position on their children's achievements, and the influence of education on access to the labor market. The main conclusions of this study were: blacks experience an upward mobility deficit that allows them to reject the idea of equal opportunities for them; the intergenerational mobility showed that among the people who were born in the lower stratum 
of rural occupation, the white population had a small advantage in the chances of social mobility; blacks were more vulnerable to downward mobility than whites; blacks were more concentrated in the lower strata of the social structure and higher educational levels had limited impact on the process of social upward mobility of blacks.

Therefore, the authors of this model confirm that social origin and racial discrimination interact in the processes of social upward mobility. Although there is evidence of barriers limiting the social upward mobility of blacks in the labor market, some individuals in this group reach prominent positions in public and private organizations in Brazil. The possibility of career advancement, even being small among the black population, reveals that, despite the existing racial barriers, one cannot rest on a deterministic and fatalistic view of social conditioning. An analysis that intends to take into account the complexity of social reality must place under suspicion both a purely deterministic view that considers racial barriers as insurmountable obstacles and a purely individualistic view that explains the processes of upward mobility solely on the basis of individual merits.

\section{THE SOCIAL MOBILITY OF BLACK MANAGERS AND THE MERIT DISCOURSE}

As already mentioned, 25 interviews were conducted with black professionals who are responsible for important areas or sectors of public and/or private organizations. We characterized the managerial work of these professionals judging the level of their responsibilities, the requirement of specific qualification for the position and the nature of their relationship with subordinates and clients / beneficiaries of the organization. Most of them had a college degree, were married, had children and a standard of living characteristic of the Brazilian middle classes. The barriers transposed by the managers we interviewed were related to the social position of the family of origin (poverty, higher number of children and level of education of parents), the need for early insertion in the labor market, the difficulty of completing the whole schooling cycle and the perception of manifestations of prejudice throughout life. When crossing this barrier, most interviewees experienced inter and intra-generational mobility, mainly motivated by the ideal of not reproducing the difficulties of their childhood and youth. We observe that all of them have ascended in the social structure when compared to the family of origin. However, episodes of racism were present in the lives of the interviewees since childhood and the early school years, as shown in the following reports:

Yeah, in my school my nickname was 'monkey.' I used to be upset about it. To this date, every black child, or black person, who enters school discovers racism. School is a place where you discover strong racism. Because in the family environment... The family protects, the family takes care of us. And it's when we go to school that we have the exact notion that you are different. And there's our hair that people are always criticizing and ridiculing and there's the color of the skin. In adolescence, in a small town, it is complex because the black girl does not have a boyfriend, it's difficult to have a relationship. (Maria, municipal public school manager).

In my school they used to say that I had bad hair. Then I would braid my hair to look better. And on the street there were always swearing [...]. I didn't 
understand very well why that used to happen. (Ana, manager of a furniture store).

There were always racist jokes at school, I did not laugh. I was upset. One day I was coming back from the library, when I was eight, and I heard someone say: he's black. I tried not to care. But I always knew that Brazil is a racist country. Since I was a child. (Ricardo, manager in a large industry.).

When I was a child I always heard jokes about my color in my school. (Flora, municipal public manager).

I always had problems with my classmates and teachers about my color. There were jokes, curses and fights. The teachers never stood by me. (Dirceu, manager in a large industry).

If in the past the social mobility of blacks was the result of patronage and affiliation by some white benefactors, today such elements are no longer present. For those interviewed, support from the family of origin, the individual's willingness to work and to qualify, persistence in the face of adversity, acceptance of organizational values and the form of reaction to discrimination seem to be more decisive for professional success. In companies, manifestations of racial prejudice were almost always related to the internalisation by whites of a negative image of blacks, especially with regard to the skills and abilities necessary for the exercise of the managerial function.

At this point it is important to emphasize that internal competition and subjective dimensions in the process of hiring and evaluating employees make the organizational environment a perfect place for discriminatory practices (BENTO, 2002). Therefore, it is necessary to consider that not always an event of discrimination in the work space is directly related to prejudice, since the discriminatory action can be primarily motivated by the maintenance of privileges, or by the search for power within the company. Nevertheless, it is important to emphasize that, even when the motivation for discrimination against black people is the maintenance of privileges, this type of discrimination, by having a very specific target (a black person), is based on racism and a vision of superiority of the notably white population.

According to Bento (2002), institutional discrimination occurs regardless of whether or not the person demonstrates open racism or the intention to discriminate. After all, for those who discriminate, we live in a racial democracy, so those who are not successful at work are regarded as the most incompetent, the least diligent and the least dedicated to work. Institutional discrimination is so effective that most of the interviewees consider themselves an exception because of the situation of the majority of blacks in the country. For them, the problem is the individual, not the institutions. This was evident in the interviews: 25 blacks were interviewed, $80 \%$ of the managers answered the questions in a quick and succinct manner, disqualifying questions about racism in the work environment, justifying their trajectory, on the basis of their personal and professional qualifications or skills, as can be observed in the following narratives:

There was a lot of internal competition in the Bank. Once I was approved in the exam, those approved in the previous exam were suspicious, because they thought I would be promoted before them. But it didn't happen. Instead, when 
I entered the Bank as an employee, a black woman entered too. We were both assigned to work in the administrative sector. There were 16 new employees. Only the both of us were black. They assigned us to work on the bank's file, which is a sector that is not visible to clients. We had no contact with the public. We worked with control and research of documents, distribution of bank statements and things like that. All white colleagues were promoted before us. We were the last ones. One day a colleague of mine, in disgust, asked the head of the sector: 'Hey, we will not have a rotation of duties here? They (me and my colleague) have been in the same sector for a long time.' The boss replied: "No, their place is here" [...] My colleague threatened to contact the union and I told him not to do that [...] After all, we were still on probationary period and that would not help us. So it took us longer than the others to move up. Among all, I was the last one to be promoted. (Rafael, manager at a public bank.)

When I took over as shopping mall operations manager, some store owners fired an anonymous e-mail with the following message: 'So the mall hired a black manager [...] What does a black man know how to do? Blacks, when they don't (sic) in the beginning, , they do in the end!, and many other things.' This email was sent to the mall administration, and to other managers. But I feel nothing, I believe that prejudice is inside people's heads. It makes no difference to me. I keep doing my job, the best as I can. When I was a child, I used to fight [...] now I don't care. But one thing is true. If there is a white person and a black person, with the same level of education, with the same knowledge and experience, the white one will be chosen. You can check in other malls in $\mathrm{BH}$ (Belo Horizonte). Have you ever seen a black person in the Administration? I don't think so. (Pedro, manager of operations of a mall).

Once I went out to lunch with my superior to discuss business of the company where I was a manager, and a curious fact happened. We walked into restaurant $Y$, ordered a bottle of wine and the waiter served only her glass. I think he thought I was her driver or her security guard. (Paulo, commercial manager in an industry).

The 25 interviewees stressed that the promotion took place because of dedication, education, professionalism, experience and good interpersonal relationships built within the organization. For most of them, their skin color and gender had no influence on the process of career mobility. According to the interviewees, overcoming racial barriers almost never involved adopting a confrontational stance. After all, 'being successful', 'getting there', occurs in this environment, which can discriminate the black population and other social minorities. It was through an individual regulation stance that managers treated the episodes of racism in the workplace. In some cases, we observed confrontation, but, in most of them, what prevailed was the lack of reaction or the disqualification of the episode by the interviewees. Bento (2003) says that there are three ways for blacks to react to situations of discrimination: denial, confrontation and non-confrontation. In denial, Blacks do not consider themselves the target of discrimination and the prejudice that affects all of society is a situation far from their reality. In the case of non-confrontation, they recognize themselves and others as the target of prejudice, but choose not to act against it. And confrontation presupposes some reaction from an individual or collective point of view. In our research, we identified that $84 \%$ of the respondents took a denial or non-confrontational stand, while only 4 of them 
(16\%) took a stance against racism. These attitudes reveal these professionals' need to disqualify race/color as a 'marker' of social differentiation.

Therefore, most managers' discourse has shown us that contradictions are concealed, favoring meritocratic discourse, which fulfills its role of hiding the social differences and injustices. And it must be reaffirmed that the strength of such discourse is so significant that even those who are victims of racial discrimination are also responsible for their reproduction. Discrimination events, at some points in the interviews, were reconstructed in order to strengthen the idea of personal effort in career mobility.

Despite the barriers and difficulties encountered by most of the interviewees in the process of professional advancement, all of them confirmed that it was their education, competence and personal effort that contributed to professional success. The color of the skin or race was perceived by many as a disadvantage that had to be overcome by commitment, qualification and dedication to work. That is, skin color, as a 'disqualifying' element for the labor market, could be neutralized by individual commitment. Thus, in contrast to the reports of discrimination present in social relations, when it comes to analyzing the reasons for career mobility, the racial issue leaves the social sphere and becomes an individual issue. This discourse is also in line with the meritocratic ideology, and it is necessary to silence all social determination that builds individuals destined to success and failure according to one social identifier or another.

When questioned about the situation of blacks in Brazil, most managers used the pronoun 'they' rather than 'we'. Expressions such as "they need to study more" or "they need to qualify" were frequent during the interviews. That means most of them did not see themselves as a member of a social group upon which prejudice and discrimination could fall on a larger scale. 'Getting there', for them, overcoming social and racial barriers, meant breaking with a stereotype that identifies the majority of blacks in Brazil as incapable and disqualified. During this research, we noticed that the interviewees' upward trajectory implied, almost always, the distancing from Afro-Brazilian culture, political-racial movements, as well as lack of knowledge of public policies aimed at the black population.

Among all the interviewees, only 05 (20\%) expressed support for affirmative action. In this sense, the process of concealment of the social sphere can also explain the position of a large part of the interviewees in relation to racial quotas, because when valuing individual merit, the construction of meritocratic discourse grounds the criterion of justice in the "result" achieved by the individual, translated as a consequence of their commitment, ability and merit.

Affirmative action, and specifically racial quota, aim to compensate the black population and other minorities of the disadvantages accumulated in the present in function of the past, promoting social actions in the field of education, work and health, among others, with the purpose of promoting equal opportunities for all individuals. Affirmative action policies admit a prospect of reparation and, at the same time, a compensatory character in order to correct present wrong doings that could jeopardize the future of young blacks (MARTINS, 2005). In addition, by ensuring equal individual opportunities, such actions turn any form of discrimination into crime. Finally, we know that the controversy surrounding the adoption (or not) of affirmative action in Brazil also contemplates a universalist dilemma, based on individual merit and equal opportunities. In their narratives, the managers focused on the 
issue of individual merit to justify their position againt these policies, as the testimonies reveal:

The quota, for example, is the greatest discrimination of all. Why is it necessary? It is not because some are able to study in private schools that it is necessary to guarantee a small percentage for blacks, no!. This policy ends up discouraging blacks, because some feel satisfied with this alms [charity]. (John, manager in an association of workers).

No, I'm not against it. Without it, it would be worse. I think it should even be expanded, because if we had equal treatment we would not need it. In public universities, if there is a black person and a white person, the white goes ahead and the black one does not; This is normal. In a big company, in a big industry, as you can see, that I already mentioned there, in the malls. You can go there, to $Y$ bank that you will not see blacks; you can't find any there. (Pedro, manager of a retail trade).

I'm not in favor. I think this is not just a racial but a financial issue. The less financial conditions the person has, the more difficult it is to reach a social level. Creating quotas for blacks does not solve the problem if the person doesn't have a basis. I, for example, had a hard time in college. The quota helps, but it's not the most efficient way to handle the issue. Teaching as a whole should improve. I have friends who don'tt have enough knowledge and have already graduated from college. (Renato, manager of a retail trade).

Another feature of meritocratic ideology, as discussed by Jessé de Souza (2011), is to blame the individual who does not "succeeds" because he believes that in today's Brazilian society, blood and birth barriers are not impediments to career mobility anymore. According to this line of thought, nowadays only the differential performance of individuals is taken into account and the notion that each one must earn according to their own merits. Cida, in her testimony, clearly indicates this functionality:

I think we have to fight. Fight to study and not lower our heads. Overcome difficulties. If I had not studied I would not be where I am. The issue of the blacks is associated with poverty. We need to make an effort to finish college. I have two sisters who studied and two who didn't follow the same trajectory, didn't study, didn't attend Higher Education. Today they're experiencing difficulties. Blacks need to study more than whites. (Cida, manager in the public sector).

However, we believe that individualism and the ideology of merit, as well as the value system that structures these views, are only "an ideological façade to mask the systematic practice of oppression and exploitation of dominated and discriminated groups" (GUIMARÃES, 1996, p. 236). In the case of this study, it conceals a strategy of undeclared racism, characteristic of Brazilian society. Another possible observation, based on this last statement, which denies the idea that racial barriers impede the upward mobility of blacks in the labor market, is based on the assumption that education is sufficient for one to overcome social inequalities, ignoring the symbolic capital that operates in distinguishing whites and blacks in the labor market. Pierre Bourdieu (2013), when describing and explaining how classification systems work, emphasizes that the signs of distinction are not restricted to the 
material domain but imply symbolic aspects, which indicate whether or not the individual is recognized as a member of a given class/fraction of a class.

So we may ask ourselves: in order to be recognized as members of a higher social class in a stratified society, would black managers have to assume and naturalize the meritocratic discourse and deny race-based affirmative action?

The data collected suggests that, in order for black managers to complete their process of upward mobility, it is not enough to just have a managerial position that translates into higher income (economic capital). It is necessary that they incorporate the values and discourse of the class they are entering (symbolic capital), among them the principle of meritocracy and the valorization of individual competence, which often means the refusal of any affirmative action.

\section{FINAL CONSIDERATIONS}

In view of the racial inequalities observed in the Brazilian labor market, we can note that it is clearly marked by differentiated situations and conditions at the time of insertion, in the construction of the occupational trajectory and also in the possibility of career mobility of whites to the detriment of blacks. However, such conditions are not recognized as manifestations of racial discrimination.

In our study, we analyzed the content of interviews conducted with 25 black managers from public and private companies in Belo Horizonte and, in the light of the works of authors such as Pierre Bourdieu, Jessé Souza and Carlos Hasenbalg, sought to identify the assumptions, functionalities and the productive character that the idea of personal merit assumes in the discourse of the interviewees as an explanation for the advancement in the professional career.

The results of the research point to the affirmation of 'merit' in the professional trajectory of the majority of the interviewees. We observed a discourse aimed at the disqualification, by the managers, of any argumentation that reinforces the racial barriers in their processes of career mobility. The managers' discourses revealed hidden or disguised contradictions for the construction of a meritocratic discourse. That way, the racism evidenced in their statements was, in most cases, relativized or silenced to strengthen the idea that their success is rooted on personal merit, and thus dismissing the social bases of discrimination. Most of them said they opposed the adoption of affirmative action policies because they believe they devalue all the efforts made by some blacks who managed to get to the highest positions in the labor market. For them, granting quotas, for example, would mean recognizing that they are unable to achieve benefits on their own. It seems that these few professionals, in disregarding the political dimension of racism in the country, place themselves in the social structure as 'winners', that is, as 'those who have gotten there', and therefore must be examples of success and achievement. Most disregard the fact that the low percentage of blacks in leadership positions, far from being an exception to the rule, reinforces the certainty that racial discrimination has not been overcome. Most are unaware that discrimination actually has two sides: while on the one hand it excludes the members of the discriminated group, on the other it benefits and facilitates the life of discriminators. 
In addition to weakening the political mobilization of the black population in the struggle in order to ascend socially, the ideology of merit also manages to cover up the subtle violence that most individuals in this group experience on a daily basis. In addition, it distances those who 'got there' from their racial identity, breaking possible ties of solidarity that could contribute to changes in racial and social inequalities. Blacks, especially those who moved up in the social structure, are forced to share the idealized version of the racial order and their pragmatic acceptance may result in a less painful way of dealing with the stigma related to the color of their skin (HASENBALG, 2005).

\section{REFERENCES}

AZEVEDO, T. As elites de cor numa cidade brasileira: um estudo de ascensão social \& classes sociais e grupos de prestígio. Salvador: EDUFBHA-EGBA, 1996.

BARBOSA, L. Igualdade e meritocracia: a ética do desempenho nas sociedades modernas. Rio de Janeiro: Editora Fundação Getúlio Vargas, 2003.

BASTIDE, R; FERNANDES, F. Relações entre negros e brancos em São Paulo. São Paulo: Cia Editora Nacional, 1955.

BENTO, M. A. S. Branqueamento e branquitude no Brasil. In: CARONE, I.; BENTO, M. A. S. (org.). Psicologia social do racismo: estudos sobre a branquitude e branqueamento no Brasil. 2. ed. Petropólis: Editora Vozes, 2003. p. 25-55.

Pactos narcísicos no racismo: branquitude e poder nas organizações empresariais e no poder público. 2002. 178f. Tese (Doutorado) - Instituto de Psicologia, Universidade de São Paulo, São Paulo, 2002.

BOURDIEU, P. A distinção: crítica social do julgamento. Tradução de Daniela Kern. Porto Alegre: Zouk, 2013.

COSTA PINTO, L. 0 negro no Rio de Janeiro: relações de uma raça numa sociedade em mudança. São Paulo: Cia Editora Nacional, 1953.

DIEESE. Departamento Intersindical de Estatística e Estudos Socioeconômicos. A situação do trabalho no Brasil. São Paulo, 2001. 352p.

FERNANDES, F. A integração do negro na sociedade de classes. São Paulo: Editora Ática, 1965.

FREYRE, G. [1936]. Sobrados \& Mucambos: decadência do patriarcado e desenvolvimento do urbano. Global: São Paulo. 2006.

GUIMARÃES, A. S. A. Racismo e anti-racismo no Brasil. São Paulo: Editora 34, 1999.

Políticas públicas para ascensão dos negros no Brasil: argumentando pela ação afirmativa. Salvador: Afro-Asia, UFBA, 1996.

HASENBALG, C. Discriminação e desigualdade raciais no Brasil. 2. ed. Belo Horizonte: Editora UFMG, 2005. 
HASENBALG, C. A. O negro no Rio de Janeiro: revisitando o projeto UNESCO. In: HASENBALG, C. A; SILVA, N. do V.; LIMA, M. (org). Cor e estratificação social. Rio de Janeiro: Contra Capa Liv., 1999. p. 60-85.

MARTINS, A. R. N. Racismo e imprensa - argumentação no discurso sobre as cotas para negros na universidade. In: SANTOS, A. S. dos (org.). Ações afirmativas e combate ao racismo nas Américas. Brasília: Ministério da Educação, 2005. p. 179-208.

OSÓRIO, R. G.. A mobilidade social dos negros brasileiros. IPEA - Texto para Discussão $\mathbf{n}$. 1033. Brasília, 2004. Available on: <http://www.ipea.gov.br/portal/>. Acess on: May 21 2009.

RODRIGUES, F. Racismo cordial. In: TURRA, C.; VENTURI, G. (org.). Racismo cordial: a mais completa análise sobre o preconceito de cor no Brasil. São Paulo: Editora Ática, 1995, p. 11-56.

SANTOS, J. R. O negro como lugar. In: MAIO, M.; SANTOS, R. Raça, ciência e sociedade. Rio de Janeiro: Editora Fiocruz, 1995.

SOUZA, J. de. A ralé brasileira: quem é e como vive. Belo Horizonte: Editora UFMG, 2011.

WEBER, M. A Ética protestante e o espírito do capitalismo. Tradução de José Marcos de Macedo. São Paulo: Cia das Letras, 2004.

Economia e Sociedade: fundamentos da sociologia compreensiva. Brasília: Editora UNB, v. 1, 2012.

Economia e Sociedade: fundamentos da sociologia compreensiva. Brasília: Editora $\overline{U N B}$, v. 2, 1999.

Data de submissão: 24/07/2017.

Data de aprovação: 24/07/2018.

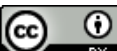

Creative Commons Atribuição 4.0 Internacional

Note: you can find this paper in Portuguese at http://www.revistaoes.ufba.br. 